\title{
Retarding of Preliminary Chemical Pollutants from Dye Industry Effluents by Metal Nano Particles, Synthesized Using Flower Extract of Catharanthus roseus
}

\author{
VIJAYA ANANDAN VEERASAMY ALAGARSAMY ${ }^{1}$, KISTAN ANDIYAPPAN ${ }^{1,2 *}$ \\ SARAL ABDUL KADAR AVULIYA ${ }^{2}$ and THAMINUM ANSARI ABUBACKER ${ }^{3}$
}

${ }^{1}$ Research and Development Centre, Bharathiar University, Coimbatore- 641046, Tamil Nadu, India

2Panimalar Institute of technology, Chennai, India.

${ }^{3} \mathrm{PG} \&$ Research Department of Chemistry, Muthurangam Government Arts College,

Vellore 632002, Tamil Nadu, India.

*Corresponding author E-mail: vishmikrish@gmail.com

http://dx.doi.org/10.13005/ojc/340141

(Received: Octuber 25, 2017; Accepted: November 29, 2017)

\section{ABSTRACT}

The present research discussed usage of 3 inorganic nano-substances in order to retard chemical pollutants from coloured effluents of dye industry and tanneries. These 3 inorganic Nano metal particles synthesized from $\mathrm{MgSO}_{4}, \mathrm{CuSO}_{4} \cdot 5 \mathrm{H}_{2} \mathrm{O}$ and $\mathrm{FeSO}_{4} \cdot 75 \mathrm{H}_{2} \mathrm{O}$ with rose petals extract Catharanthus roseus. To assess the feasibility of using these nano particles as low-cost adsorbents for suppressing preliminary chemical pollutants in coloured effluents. Also compared and investigated the ability of these 3 nano materials due to using flower extract of Catharanthus roseus petals, in order to retard preliminary chemical pollutants quantity such as $\mathrm{pH}$, Alkalinity, hardness, TDS, BOD, COD, Sulphide, Sulphate, Nitrate, Ca, Mg, Phosphate, Na and K. These synthesized 3 nano materials characterized by UV-Visible spectroscopic analysis, FT-IR Spectroscopic analysis and, X-ray Diffraction (XRD) studies.

Keywords: Nano materials, Catharanthus roseus, Low cost adsorbent, Preliminary pollutants, Dye effluents.

\section{INTRODUCTION}

Now a day we know numerous management approaches to remove contaminants from dye industry and tannery sewage. This removal process can be carried out by physical, chemical, and biological processes ${ }^{1}$. In the chemical management procedure, many advanced process such as UV, $\mathrm{H}_{2} \mathrm{O}_{2}$, photo-catalyst and Fenton's agent are often used and have been proven effective in the quick elimination of colours and pollutants from dye solutions ${ }^{2}$. Over the previous few years adsorption

This is an $\mathbf{C}$ Open Access article licensed under a Creative Commons Attribution-NonCommercial-ShareAlike 4.0 International License (https://creativecommons.org/licenses/by-nc-sa/4.0/ ), which permits unrestricted NonCommercial use, distribution and reproduction in any medium, provided the original work is properly cited. 
has gained paramount importance in industry and surroundings protection. Adsorbents are generally used for its environment pleasant conduct, availability in nature and are very a good deal-price powerful. Metal Nano particles can be used as effective bio-adsorbent for removing with dyes metals and natural pollutants from industrial wastewater.

However those technologies usually having some disadvantages, such as complicated procedure, high expenses, forming by-products and removal of those by-products. For example activated carbon is typically extra effective to adsorb numerous pollutants than other adsorbents which do now not require massive processing ${ }^{3}$. But, commercially available activated carbon is highlypriced and might not be cost effective for colored wastewater remedy. For a cost-effective colored wastewater remedy purpose, therefore the improvement of recent materials from no price or low cost adsorbents obtained domestically is a thrilling alternative. Many research had been investigated the remedy of dye effluents containing a single dye or a aggregate of the identical magnificence of dyes, as well as chemical contaminants however the treatment of mixtures containing distinct lessons of dyes has not been sufficiently addressed ${ }^{4}$. The present look at investigates the effectiveness of adsorption as a treatment manner for a disperse dye, a reactive dye and their aqueous mixtures, in phrases of retardation of chemical parameters consisting of $\mathrm{pH}$, alkalinity, hardness, TDS, BOD, COD reduction the usage of inorganic synthesized nano materials $\left(\mathrm{MgSO}_{4}, \mathrm{CuSO}_{4} 5 \mathrm{H}_{2} \mathrm{O}, \mathrm{FeSO}_{4} \cdot 7 \mathrm{H}_{2} \mathrm{O}\right)$.

Novelty of present study was some inorganic metal Nanoparticles are synthesized by using the flower extract of the plant Catharanthus roseus (also known as periwinkle) belongs to the family Apocyanaceae; it grows as a shrub in subtropical areas. The plant produces flowers with five petals and the flowers are of three types. Rose purple flowers, white flowers and white flowers with a rose purple spot in the centre. The first type is most commonly found and it is more cultivated because of its higher alkaloid content. This plant has been taken for study due to its unique properties. This examine was achieved to make use of the steel
Nano particles as a low value adsorbent with recognize to numerous parameters together with exclusive doses, contact time and $\mathrm{pH}$. The characterizations of these Nanoparticles were done by FTIR, UV-spectroscopy, and XRD analysis.

\section{MATERIALS AND METHODS}

\section{Preparation of rose extracts}

Materials used for the synthesis of Nano particles are $\mathrm{MgSO}_{4}, \mathrm{CuSO}_{4} \cdot 5 \mathrm{H}_{2} \mathrm{O}, \mathrm{FeSO}_{4} \cdot 7 \mathrm{H}_{2} \mathrm{O}$, were purchased from Merck-chemical company, India. The flowers of the plant Catharanthus roseus were collected from rose garden. $10 \mathrm{~g}$ wet flowers petals were weighed and washed twice with distilled water followed by Millipore water and then macerated into fine pieces. These fine flower petal pieces taken in a $250 \mathrm{ml}$ Erlenmeyer flask, $50 \mathrm{ml}$ of Millipore water was added and kept on a water bath for $15 \mathrm{~min}$. at $750{ }^{\circ} \mathrm{C}$. Then the flowers content was filtered off through whatman 40 clear out paper after which extract become used for the synthesis of diverse metals nano debris which includes $\mathrm{MgSO}_{4}$ $\mathrm{CuSO}_{4} \cdot 5 \mathrm{H}_{2} \mathrm{O}$, and $\mathrm{FeSO}_{4} \cdot 7 \mathrm{H}_{2} \mathrm{O}$. This extract stands stable for one week if stored at $30 \pm 5^{\circ} \mathrm{C}$.

\section{Synthesis of Metal Nano particles using Rose petal extract \\ Synthesis of $\mathrm{MgSO}_{4}$ Nano particle}

$200 \mathrm{ml}$ of the solution of $\mathrm{MgSO}_{4}(4.92 \mathrm{~g})$ and then stirred by magnetic stirring (1000 Rpm) for $60 \mathrm{~min}$. and then this mixture was added slowly with constant agitation in the titrant of $200 \mathrm{ml}$ of $\mathrm{NaOH}(0.1 \mathrm{~N})$ solution then precipitate was obtained. This precipitate was filtered and dried at the oven $150^{\circ} \mathrm{C}$. The precipitate obtained in this process was characterized by UV-Visible spectroscopic analysis, FT-IR Spectroscopic analysis, X-ray diffraction studies.

\section{Synthesis of $\mathrm{CuSO}_{4} \cdot 5 \mathrm{H}_{2} \mathrm{O}$ Nano particle}

$200 \mathrm{ml}$ of the solution of $\mathrm{CuSO}_{4} \cdot 5 \mathrm{H}_{2} \mathrm{O}(4.99 \mathrm{~g})$ and then stirred by magnetic stirring (1000Rpm) for $60 \mathrm{~min}$. and then this mixture was added slowly with constant agitation in the titrant of $200 \mathrm{ml}$ of $\mathrm{NaOH}$ $(0.1 \mathrm{~N})$ solution then precipitate was obtained. This precipitate was filtered and dried at the oven $150{ }^{\circ} \mathrm{C}$. The precipitate obtained in this process was characterized by UV-Visible spectroscopic analysis, FT-IR Spectroscopic analysis, X-ray Diffraction Studies. 


\section{Synthesis of $\mathrm{FeSO}_{4} \cdot 7 \mathrm{H}_{2} \mathrm{O}$ Nano particle}

$200 \mathrm{ml}$ of the solution of $\mathrm{FeSO}_{4} \cdot 7 \mathrm{H}_{2} \mathrm{O}(5.56 \mathrm{~g})$ and then stirred by magnetic stirring (1000 Rpm) for $60 \mathrm{~min}$. and then this mixture was added slowly with constant agitation in the titrant of $200 \mathrm{ml}$ of $\mathrm{NaOH}(0.1 \mathrm{~N})$ solution then precipitate was obtained. This precipitate was filtered and dried at the oven $150{ }^{\circ} \mathrm{C}$. The precipitate obtained in this process was characterized by UV-Visible spectroscopic analysis, FT-IR Spectroscopic analysis, X-ray diffraction studies.

\section{Characterization of metal nano particles UV-Visible spectroscopic analysis}

UV-Visible spectra of all the nanoparticle were recorded using de-ionized water $\left(\mathrm{H}_{2} \mathrm{O}\right)$ as solvent ${ }^{6}$. The UV-Visible spectra of Rose extract and metal nanoparticle are given in Fig. 1-3, and the values are shown in Table. 1.The spectrum reveals the characteristic absorption peaks of Nanoparticle material at $200-590 \mathrm{~nm}$ respectively. The maximum peak was observed at $380 \mathrm{~nm}$ and minimum peak was observed at $230 \mathrm{~nm}$ which corresponds to Nano size of $\mathrm{MgSO}_{4}$. The maximum peak was observed at $590 \mathrm{~nm}$ and minimum peak was observed at $390 \mathrm{~nm}$ which corresponds to Nano size of $\mathrm{CuSO}_{4} \cdot 5 \mathrm{H}_{2} \mathrm{O}$. The maximum peak was observed at $393 \mathrm{~nm}$ and minimum peak was observed at $242 \mathrm{~nm}$ which corresponds to nano

Table. 1: UV-Visible spectral data of different metal nano particle

\begin{tabular}{cc}
\hline Types of Nano materials & $\lambda_{\text {max }}(\mathrm{nm})$ \\
\hline $\mathrm{MgSO}_{4}$ & $235 \& 380$ \\
$\mathrm{CuSO}_{4} \cdot 5 \mathrm{H}_{2} \mathrm{O}$ & $390 \& 590$ \\
$\mathrm{FeSO}_{4} \cdot 7 \mathrm{H}_{2} \mathrm{O}$ & $242 \& 393$ \\
\hline
\end{tabular}

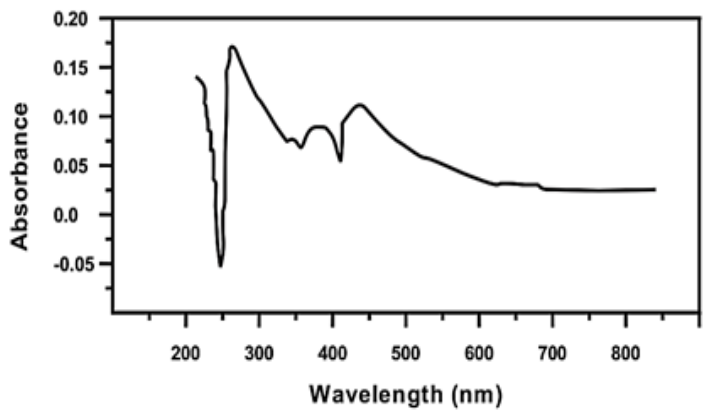

Fig. 1. UV-Spectral Analysis of $\mathrm{MgSO}_{4}$ Nanoparticl size of $\mathrm{FeSO}_{4} \cdot 7 \mathrm{H}_{2} \mathrm{O}$. UV-Visible Spectra revealed that concentration of aqueous extract of Catharanthus roseus plays an important role in the charge transfer from oxygen to the center; one can expect to see the metal field transition in these cases.

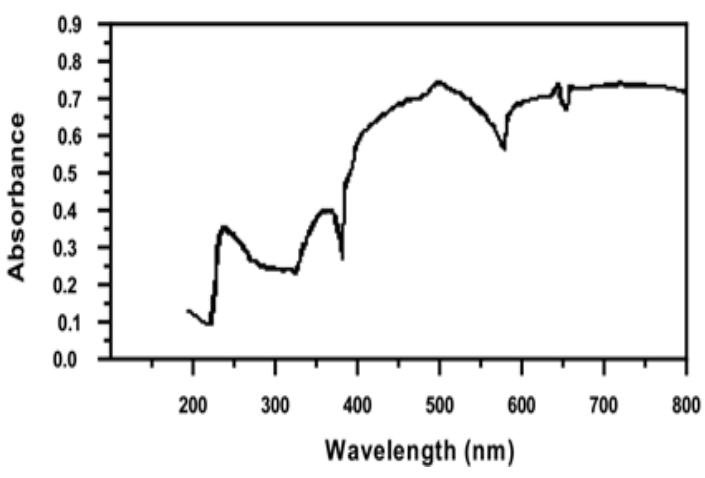

Fig. 2. UV-Spectral Analysis of $\mathrm{CuSO}_{4}$ Nanoparticle

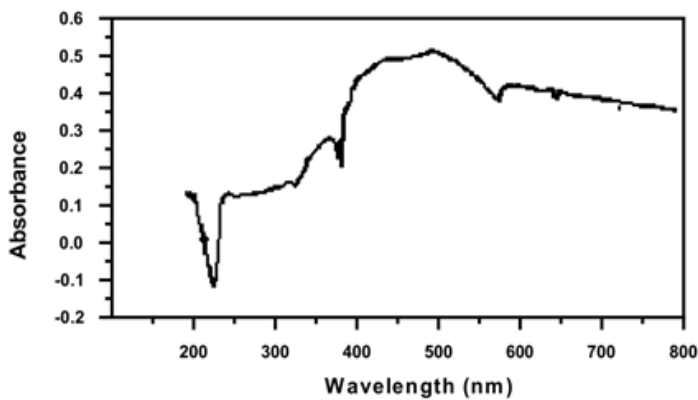

Fig. 3. UV -Spectral Analysis of $\mathrm{FeSO}_{4} \cdot 7 \mathrm{H}_{2} \mathrm{O}$ Nanoparticle

\section{FT-IR Spectroscopic analysis}

FT-IR spectrum of the metal nano particles shows peak at $500 \mathrm{~cm}^{-1}$ to $650 \mathrm{~cm}^{-1}$ which is attributed to the presence of metal in the nanoparticle. The band at $3850.22 \mathrm{~cm}^{-1}-1481.48$ $\mathrm{cm}^{-1}, 1078.41 \mathrm{~cm}^{-1}-899.21 \mathrm{~cm}^{-1}$ and $3682.12 \mathrm{~cm}^{-1}$ $988.88 \mathrm{~cm}^{-1}$ are attributed to $\mathrm{MgSO}_{4}, \mathrm{CuSO}_{4} \cdot 5 \mathrm{H}_{2} \mathrm{O}$ and $\mathrm{FeSO}_{4} \cdot 7 \mathrm{H}_{2} \mathrm{O}$ stretching mode of vibration for the benzenoid units of rose extract. The FT-IR spectroscopic analysis of rose extract and metal Table. 2: IR-Vibration Frequencies for the Rose Extract and Metal Nanoparticle

\begin{tabular}{lc} 
Types of Nano materials & Wave number $\left(\mathrm{cm}^{-1}\right)$ \\
\hline $\mathrm{MgSO} 4$ & $3850.22 \&$ \\
1481.48 & \\
$\mathrm{CuSO}_{4} \cdot 5 \mathrm{H}_{2} \mathrm{O}$ & $1078.41 \& 899.21$ \\
$\mathrm{FeSO}_{4} \cdot 7 \mathrm{H}_{2} \mathrm{O}$ & $3682.12 \& 988.88$ \\
\hline
\end{tabular}




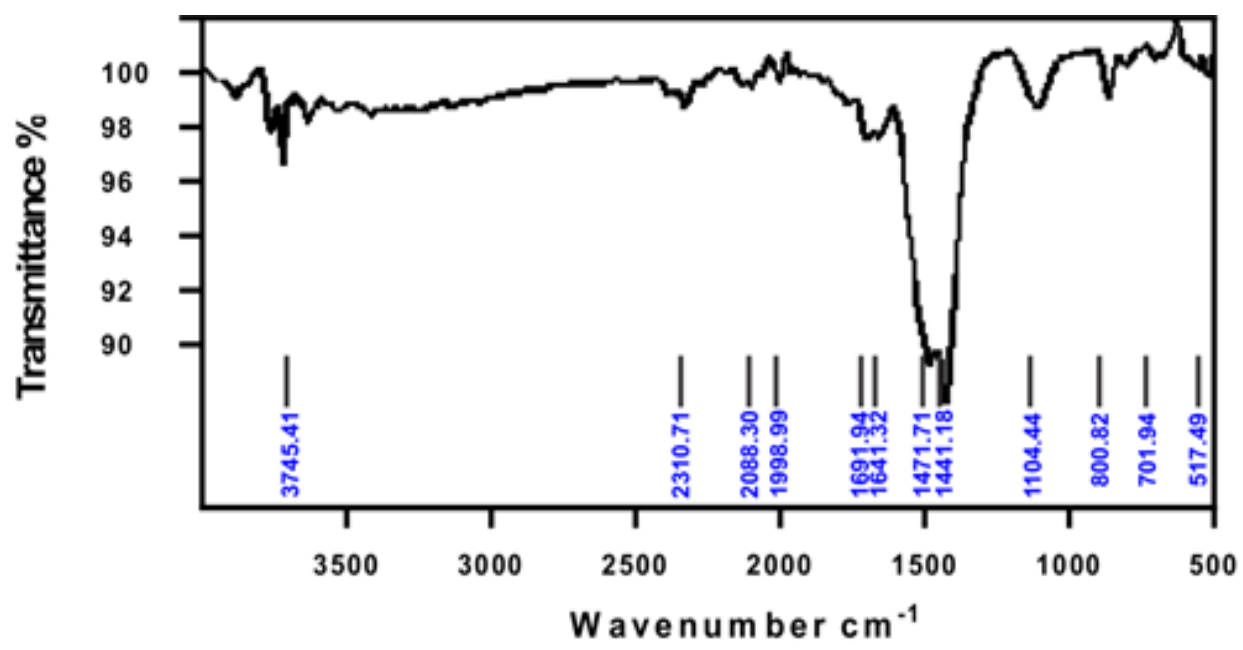

Fig. 4. IR-Spectral Analysis of $\mathrm{MgSO}_{4}$ Nanoparticle

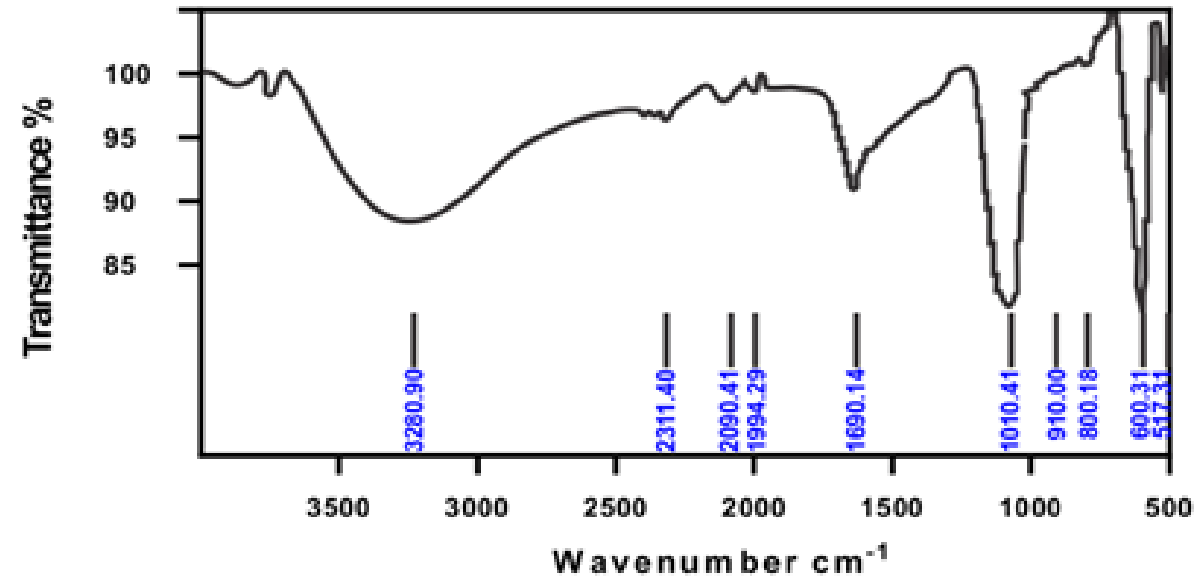

Fig. 5. IR-Spectral Analysis of $\mathrm{CuSO}_{4}$ Nanoparticle

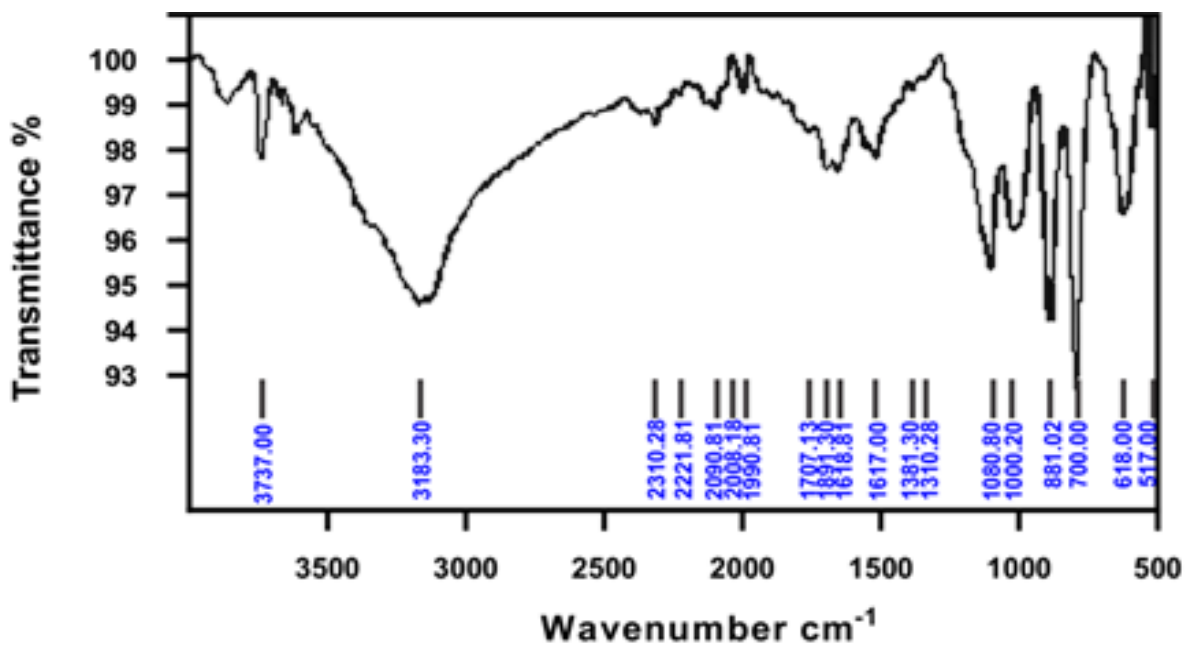

Fig. 6. IR-Spectral Analysis of $\mathrm{FeSO}_{4} \cdot 7 \mathrm{H}_{2} \mathrm{O}$ Nanoparticle 
Nanoparticle are given in Fig. 4-6, and the values are shown in Table. 2.

\section{X-ray Diffraction Studies}

Figure. 7 -9 shows the XRD pattern of $\mathrm{MgSO}_{4}, \mathrm{CuSO}_{4} \cdot 5 \mathrm{H}_{2} \mathrm{O}$ and $\mathrm{FeSO}_{4} \cdot 7 \mathrm{H}_{2} \mathrm{O}$ nanoparticles. XRD diffraction patterns of $\mathrm{MgSO}_{4}, \mathrm{CuSO}_{4} .5 \mathrm{H}_{2} \mathrm{O}$ and $\mathrm{FeSO}_{4} \cdot 7 \mathrm{H}_{2} \mathrm{O}$ nanoparticles. On comparison with the JCPDS data's (21-1272, 04-0836, 85-1436, 89-1397,04-0836) reveals that the crystalline structure of nanoparticles which are Hexagonal, Cubic, Spinel Cubic, Structure ${ }^{7}$. Average particle diameter $D$ for specimen was obtained from the main peak using Debye-Scherrer equation (1) for the peak width broadening as a function of the size of the particles.

$$
\mathrm{D}=0.89 / \beta \cos \theta \rightarrow
$$

Here $\lambda$ is the $x$-ray wavelength $\left(\mathrm{K} \alpha=1.5418 \mathrm{a}^{\circ}\right), \mathrm{k}$ is the system constant $(0.89), \beta$ is the total width at half most of the peak and $\theta$ is the peak function and using the above method we obtained a median length for debris with the greater intense height of the plane for sample ${ }^{8}$. The average size of the nanoparticles was shown in Table. 3. XRD study clearly confirms that the formation of rose extract dispersed in nanoparticles which are, $\mathrm{MgSO}_{4}, \mathrm{CuSO}_{4} \cdot 5 \mathrm{H}_{2} \mathrm{O}$ and $\mathrm{FeSO}_{4} \cdot 7 \mathrm{H}_{2} \mathrm{O}$.

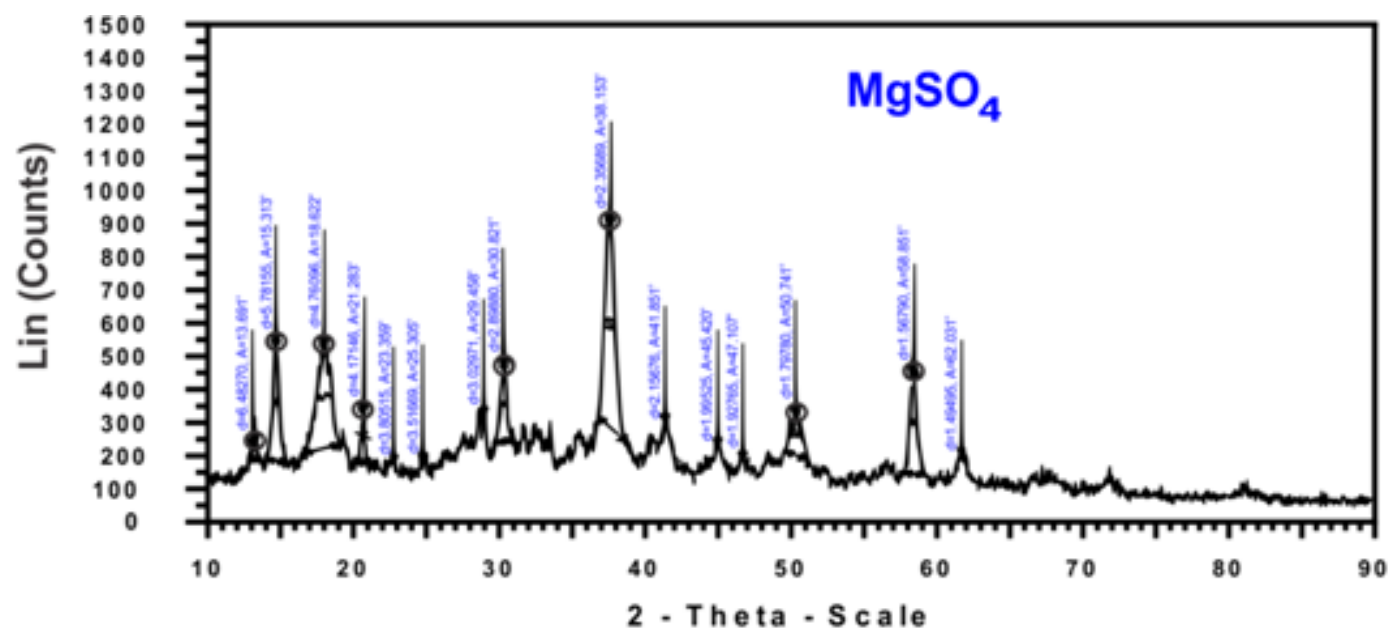

Figure: 7 XRD-Spectral Analysis of $\mathrm{MgSO}_{4}$ Nanoparticle

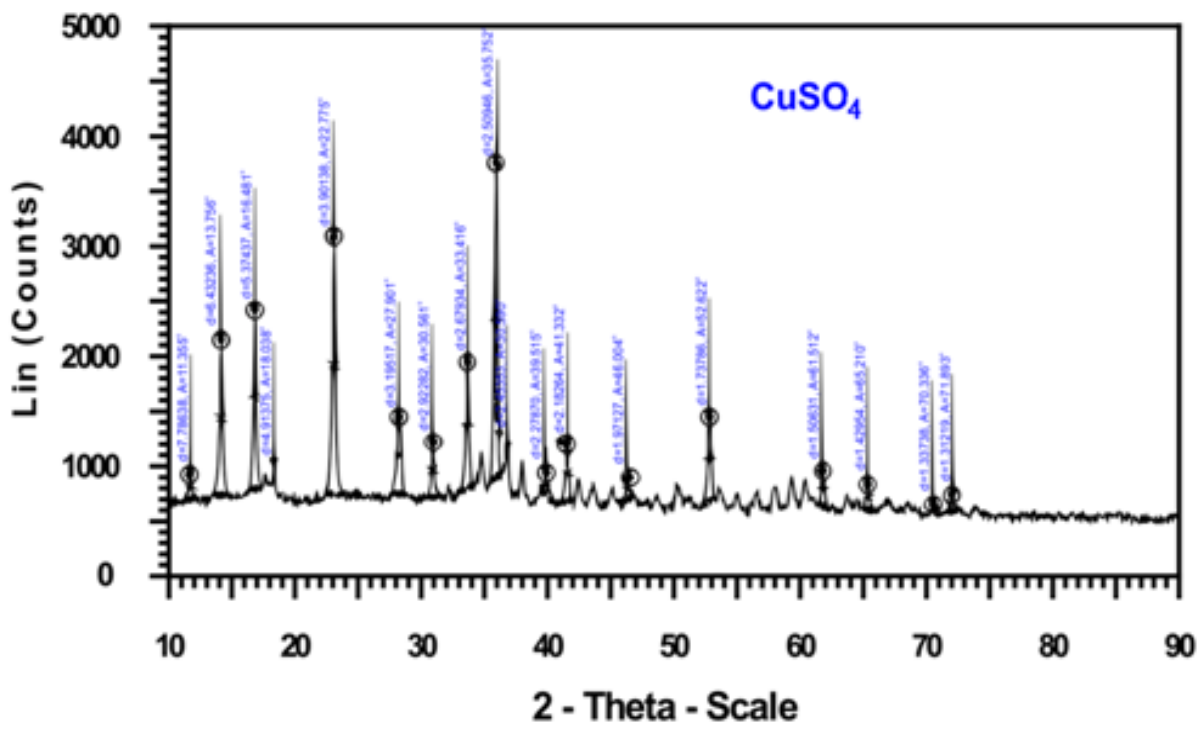

Fig.8.XRD-Spectral Analysis of $\mathrm{CuSO}_{4}$ Nanoparticle 


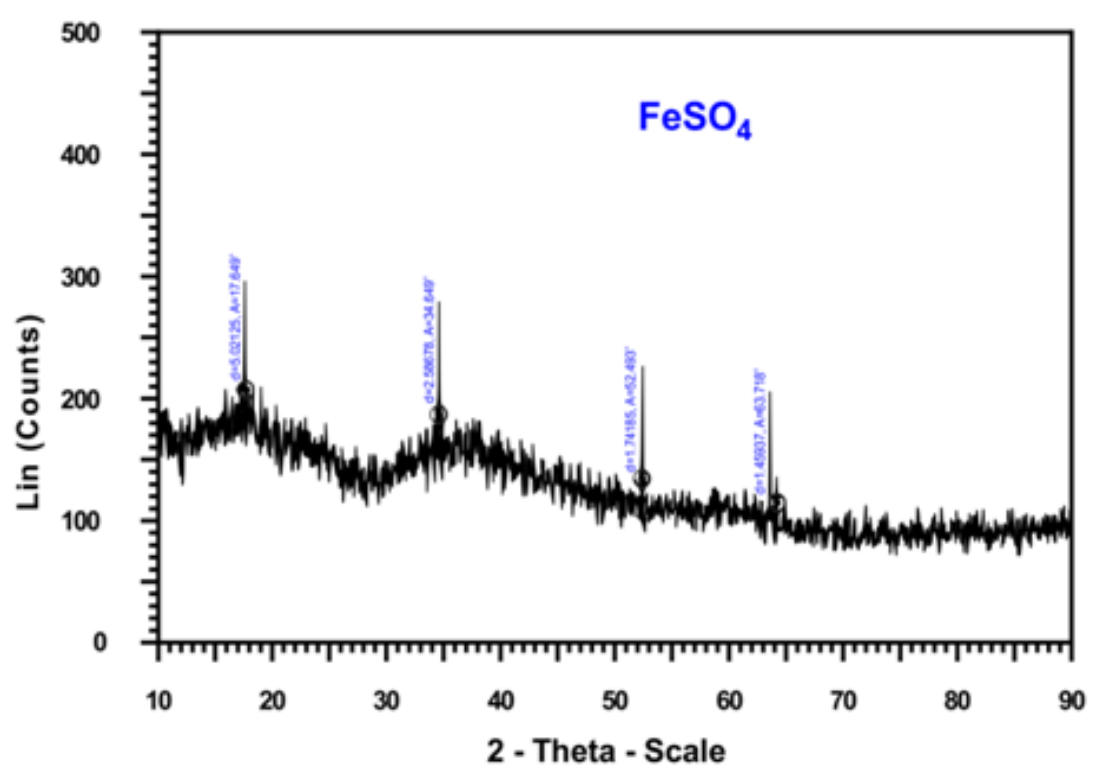

Fig. 9. XRD-Spectral Analysis of $\mathrm{FeSO}_{4} \cdot 7 \mathrm{H}_{2} \mathrm{O}$ Nanoparticle

Table.3: X-ray Diffraction Studies for the Rose Extract and Metal Nanoparticles

Types of XRD Average Crystalline $2(\theta)$ Nanoparticles Size (D)nm

Compund

\begin{tabular}{lcc}
\hline $\mathrm{MgSO}_{4}$ & 7.220 & 18.622 \\
$\mathrm{CuSO}_{4} .5 \mathrm{H}_{2} \mathrm{O}$ & 35.019 & 18.038 \\
$\mathrm{FeSO}_{4} .7 \mathrm{H}_{2} \mathrm{O}$ & 29.98 & 63.718 \\
\hline
\end{tabular}

\section{Methodology}

Analytical analysis

The Physico-chemical parameters such as $\mathrm{pH}$, TDS, BOD, COD, Total alkalinity, Potassium, Calcium, Magnesium, Sulphides, Chlorides, Chromium and Nitrates were determined, the chemical characteristics including heavy metals for examination of water ${ }^{10}$.

The physico-chemical parameters such as $\mathrm{pH}$, TDS, BOD, COD, overall Alkalinity, Potassium, Calcium, Magnesium, Sulphides, Chlorides, Chromium and Nitrate have been measured on the sample web page the usage of hand held analyzing kits. Ground water samples have been amassed and the samples were saved in a polythene bottle for similarly laboratory analysis of fundamental ions. The extra natural analytical reagents and chemical requirements had been used for the groundwater excellent assessment. The water samples were analyzed in Tamilnadu Water Supply and Drainage Board, Vellore.4.

The analytical techniques are suggested by the American Public Fitness Association ${ }^{11}$. $\mathrm{pH}$ was determined by electrometric method by using $\mathrm{pH}$ meter. (Alkalinity) Carbonate and bicarbonate were determined using acid - base titration method; Total alkalinity was measured by potentiometric titration method. TDS was determined by Gravimetric method. Chloride concentration was measured by Argentometric method, Sulphate and sulphide measured by Colorimetric method using spectrophotometer, Nitrate was analyzed using Kjeldhal flask apparatus. Calcium and Magnesium were determined using the EDTA titration method Chromium were determined by Flame Atomic Absorption Spectrophotometer (VARIAN SPECTRA A240) in CVR Labs Pvt. Ltd, Saidapet, Chennai-5, Tamilnadu.

\section{Pretreatment with metal nano particles}

Waste water samples from equalization cum collection tank were taken in four 1 litre graduated glass jars. To each of the sample with three metal nano particles namely $\mathrm{MgSO}_{4}$ $\mathrm{CuSO}_{4} \cdot 5 \mathrm{H}_{2} \mathrm{O}$, and $\mathrm{FeSO}_{4} \cdot 7 \mathrm{H}_{2} \mathrm{O}$ at various concentrations (10 mg/lit., $20 \mathrm{mg} / \mathrm{lit}$., $30 \mathrm{mg} / \mathrm{lit}$., and $40 \mathrm{mg} / \mathrm{lit}, 50 \mathrm{mg} / \mathrm{lit}$.) were added and allowed to settle 
for 12 hours. The supernatant liquid was used for the tests of various parameters such as $\mathrm{pH}, \mathrm{COD}$, BOD, chlorides, Sulphide, hardness, alkalinity, Nitrate and TDS by quantitative methods.

\section{RESULT AND DISCUSSION}

The waste water samples from equalization cum collection tanks of selected dye industries were collected and characterized for $\mathrm{pH}$, COD, BOD, SS and TDS, the data are presented in Table . 4.

Table.4: Characterization of raw sample

\begin{tabular}{lll}
\hline S.NO Parameters & Unit & $\begin{array}{c}\text { Before adding } \\
\text { adsorbents }\end{array}$ \\
\hline
\end{tabular}

\begin{tabular}{lllc} 
1. & $\mathrm{pH}$ at $25^{\circ} \mathrm{C}$ & $\mathrm{Number}$ & 8.5 \\
2. & $\begin{array}{l}\text { Total Dissolved } \\
\text { solids at } 180^{\circ} \mathrm{C}\end{array}$ & $\mathrm{Mg} / \mathrm{L}$ & 15,216 \\
3. & Chlorides as $\mathrm{Cl}$ & $\mathrm{Mg} / \mathrm{L}$ & 3500 \\
4. & Sulphide as $\mathrm{SO}_{4}$ & $\mathrm{Mg} / \mathrm{L}$ & 1900 \\
5. & BOD (at $27^{\circ} \mathrm{C}$ & $\mathrm{Mg} / \mathrm{L}$ & 600 \\
& for 3 days) & & \\
6. & COD & $\mathrm{Mg} / \mathrm{L}$ & 3400 \\
7. & Alkalinity & $\mathrm{Mg} / \mathrm{L}$ & 7000 \\
8. & Total hardness & $\mathrm{Mg} / \mathrm{L}$ & 4500 \\
9. & Calcium & $\mathrm{Mg} / \mathrm{L}$ & 3000 \\
10. & Magnesium & $\mathrm{Mg} / \mathrm{L}$ & 900 \\
11. & Sulphide & $\mathrm{Mg} / \mathrm{L}$ & 27 \\
12. & Phosphate & $\mathrm{Mg} / \mathrm{L}$ & 1.59 \\
13. & Sodium & $\mathrm{Mg} / \mathrm{L}$ & 800 \\
14. & Potassium & $\mathrm{Mg} / \mathrm{L}$ & 30 \\
15. & Nitrate & $\mathrm{Mg} / \mathrm{L}$ & 5.10 \\
\hline
\end{tabular}

The BOD/COD ratio can likely to be increased remaining certain residual nonbiodegradable organic materials and chemicals in the dye waste water. The settling rate of sludge appeared from primary liquor was observed to be 0.024 . Actually the BOD/COD ratio which is an index of waste water was found to be in the range of 0.15 to 0.35 . The settling rate of sludge is a function of particle size and viscosity of the medium. The size of the particles can be increased during adsorption and flocculation due to the addition of adsorbents.
Chemical adsorption consists of adding small amount of certain adsorbent to waste water which form flocculation precipitate that coalesce the suspended impurities can cause force to settle out rapidly. Adsorbent consists of a series of operation that result in the destabilization of the colloids leading to their removal from the suspended fluid. Ideally it is possible to distinguish from sequential steps in adsorption namely.

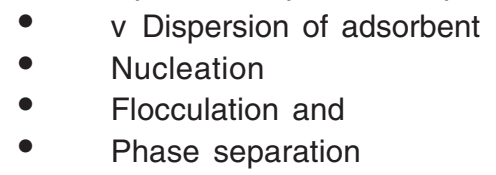

In current practice, PACL is used as the best adsorbent for dye waste water. The quantity of adsorbent $\mathrm{PACL}$ required for adsorptionflocculation of waste water was optimized for the removal of suspended solid and other organics in it. The results that were obtained for optimum dosage of alum as coagulant was already studied.

PACL is the best adsorbent for dye effluent. The quantity of the adsorbent was optimized in the preliminary investigations Table. 2 . In the acidic location, PACL starts to hydrolyze and paperwork monomeric al hydrolyzed species. Subsequently, soluble cations such as $\mathrm{Al}^{3+}, \mathrm{Al}(\mathrm{OH})^{2+}$ and $\mathrm{Al}(\mathrm{OH})^{2+}$ are most important within the answer. They play an important role in destabilizing the negatively charged dye debris via fee neutralization. At around impartial $\mathrm{pH}, \mathrm{Al}(\mathrm{III})$ has constrained solubility because of the precipitation of amorphous hydroxide, which results in the possibility of sweep flocculation as impurities (i.e., dye particles) enmesh inside the developing precipitates and are efficaciously removed. The main purpose of this study is the new adsorbents namely $\mathrm{MgSO}_{4}$, $\mathrm{CuSO}_{4} \cdot 5 \mathrm{H}_{2} \mathrm{O}, \mathrm{FeSO}_{4} \cdot 7 \mathrm{H}_{2} \mathrm{O}$ and were introduced and tried for the first time, as adsorbent for textile industry dye effluent to know their removal efficiencies in controlling various pollution causing parameters of dye effluents and their effectiveness were compared with that of Pearl Agrotech Corporation Limited (PACL).

The values presented in the tables were the results obtained for samples with different nano materials in various concentrations. And also the 
graphs were plotted for reduction of physico chemical pollutants against dosages of synthesized nano materials Adsorbent.

The present study further extended to employ new adsorbents, metal nano particles synthesized using rose petals (catharanthus roseus) such as $\mathrm{MgSO}_{4} \mathrm{CuSO}_{4} \cdot 5 \mathrm{H}_{2} \mathrm{O}$ and $\mathrm{FeSO}_{4} \cdot 7 \mathrm{H}_{2} \mathrm{O}$ to compare the results with those obtained with PACL. Data obtained for the different complexes are presented in Tables. 5, 9.

\section{Effect of $\mathrm{MgSO}_{4}$ nano particles on vat dye combined waste water}

The $\mathrm{pH}$ of the raw effluent was 8.5 it was decreases to $8.5,8.6,8.8,8.9$, and 9.4 with addition of $10 \mathrm{mg} / \mathrm{lit}$., $20 \mathrm{mg} / \mathrm{lit}$., $30 \mathrm{mg} / \mathrm{lit}$., $40 \mathrm{mg} / \mathrm{lit}, 50 \mathrm{mg} / \mathrm{lit}$ of $\mathrm{MgSO}_{4}$ nano particles respectively Table. 5 due to the basic nature of the coagulant. The increase of $\mathrm{pH}$ might due to the release of the hydroxide ions in the complexes depict the change of $\mathrm{pH}$ as a function of the coagulant concentration.

The Total Dissolved Solid value of the raw effluent was $15,216 \mathrm{mg} / \mathrm{L}$ and decrease to 6520 $\mathrm{mg} / \mathrm{L}, 6490 \mathrm{mg} / \mathrm{L}, 6471 \mathrm{mg} / \mathrm{L}, 6432 \mathrm{mg} / \mathrm{L}$ and $6330 \mathrm{mg} / \mathrm{L}$ with the addition of $10 \mathrm{mg} / \mathrm{lit}$, $20 \mathrm{mg} / \mathrm{lit}$., $30 \mathrm{mg} / \mathrm{lit}$., $40 \mathrm{mg} / \mathrm{lit}, 50 \mathrm{mg} / \mathrm{lit}$ of $\mathrm{CuSO}_{4} \cdot 5 \mathrm{H}_{2} \mathrm{O}$ nano particles respectively Table. 5 . It was observed that there was reduction of TDS was imparted by the $\mathrm{MgSO}_{4}$ nano particles added. The main objective of chemical treatment is to remove colloids carried by the effluent. Since colloidal particles are charged particles, and these charged particle trapped using complexes carrying opposite charges in order to form flock and create density gradient between liquid and suspended solid phase (to reduce zeta potential of suspended colloidal particles).

The chloride value of the raw effluent was $3500 \mathrm{mg} / \mathrm{lit}$. It was decreases to $1194 \mathrm{mg} / \mathrm{lit}, 1183$ $\mathrm{mg} / \mathrm{lit}, 1143 \mathrm{mg} / \mathrm{lit} ., 1168 \mathrm{mg} / \mathrm{lit}$, and $1127 \mathrm{mg} / \mathrm{lit}$ with the addition of $10 \mathrm{mg} / \mathrm{lit}$., $20 \mathrm{mg} /$ lit., $30 \mathrm{mg} /$ lit., 40 $\mathrm{mg} / \mathrm{lit}$, and $50 \mathrm{mg} / \mathrm{lit}$. of $\mathrm{MgSO}_{4}$ nano particles respectively Table. 5 . The reduction in the chloride value might be due to the replacement of chloride by perchlorate ions in plain sedimentation.
The sulphate value of the raw effluent was $1900 \mathrm{mg} / \mathrm{lit}$. It was decreases to1397 mg/lit, 1351 $\mathrm{mg} / \mathrm{lit}, 1297 \mathrm{mg} / \mathrm{lit}, 1275 \mathrm{mg} / \mathrm{lit}$ and $1243 \mathrm{mg} / \mathrm{lit}$. with the addition of $10 \mathrm{mg} /$ lit., $20 \mathrm{mg} / \mathrm{lit}$., $30 \mathrm{mg} / \mathrm{lit}$., 40 $\mathrm{mg} / \mathrm{lit}, 50 \mathrm{mg} / \mathrm{lit}$ of $\mathrm{MgSO}_{4}$ nano particles respectively Table. 5. The reduction in the Sulphate value might be due to the oxidation of Sulphate form into elementary sulphur, which formed flocculation and undergo plain sedimentation.

The BOD of the raw effluent was $350 \mathrm{mg} / \mathrm{lit}$ and decreases to $324 \mathrm{mg} / \mathrm{lit}, 312 \mathrm{mg} / \mathrm{lit}, 298 \mathrm{mg} / \mathrm{lit}$, $286 \mathrm{mg} / \mathrm{lit}$, and $273 \mathrm{mg} / \mathrm{lit}$ with the addition of 10 $\mathrm{mg} / \mathrm{lit}$., $20 \mathrm{mg} / \mathrm{lit}$., $30 \mathrm{mg} / \mathrm{lit}$., $40 \mathrm{mg} / \mathrm{lit}, 50 \mathrm{mg} / \mathrm{lit}$ of $\mathrm{MgSO}_{4}$ nano particles respectively Table. 5 . The decrease in BOD might be due to coagulating effect of the complex with bio-organic compounds. It is evident that heavy metals are toxic to aquatic microorganisms beyond certain concentration.

The COD value of the raw effluent was $2311 \mathrm{mg} / \mathrm{lit}$ and decrease to $2198 \mathrm{mg} / \mathrm{lit}, 2143 \mathrm{mg} /$ lit, $2083 \mathrm{mg} / \mathrm{lit}, 2041 \mathrm{mg} / \mathrm{lit}$, and $2005 \mathrm{mg} / \mathrm{lit}$ with the addition of $10 \mathrm{mg} /$ lit., $20 \mathrm{mg} / \mathrm{lit}$., $30 \mathrm{mg} / \mathrm{lit}$., $40 \mathrm{mg} /$ lit, $50 \mathrm{mg} / \mathrm{lit}$ of $\mathrm{MgSO}_{4}$ nano particles respectively Table. 5. This reduction in COD might be due to nitrogenous increment in waste water by addition of dosed $\mathrm{MgSO}_{4}$ nano particles.

The Alkalinity of the raw effluent was 2860 $\mathrm{mg} / \mathrm{lit}$ and decrease to $2630 \mathrm{mg} / \mathrm{lit}, 2542 \mathrm{mg} / \mathrm{lit}, 2367$ $\mathrm{mg} / \mathrm{lit}, 2277 \mathrm{mg} / \mathrm{lit}$, and $2168 \mathrm{mg} / \mathrm{lit}$ with the addition of $10 \mathrm{mg} / \mathrm{lit}$., $20 \mathrm{mg} / \mathrm{lit}$., $30 \mathrm{mg} / \mathrm{lit}$., $40 \mathrm{mg} / \mathrm{lit}, 50 \mathrm{mg} / \mathrm{lit}$ of $\mathrm{MgSO}_{4}$ nano particles respectively Table. 5.

The total hardness of the raw effluent was $2000 \mathrm{mg} / \mathrm{lit}$ and decrease to $1414 \mathrm{mg} / \mathrm{lit}, 1383 \mathrm{mg} /$ lit, $1375 \mathrm{mg} / \mathrm{lit}, 1366 \mathrm{mg} / \mathrm{lit}$, and $1361 \mathrm{mg} / \mathrm{lit}$ with the addition of $10 \mathrm{mg} / \mathrm{lit}$., $20 \mathrm{mg} / \mathrm{lit}$., $30 \mathrm{mg} / \mathrm{lit}$., $40 \mathrm{mg} / \mathrm{lit}$, $50 \mathrm{mg} / \mathrm{lit}$ of $\mathrm{MgSO}_{4}$ nano particles respectively Table. 5.

The calcium value of the raw effluent was $1080 \mathrm{mg} / \mathrm{lit}$ and decrease to $926 \mathrm{mg} / \mathrm{lit}, 904 \mathrm{mg} / \mathrm{lit}$, $891 \mathrm{mg} / \mathrm{lit}, 876 \mathrm{mg} / \mathrm{lit}$, and $863 \mathrm{mg} / \mathrm{lit}$ with the addition of $10 \mathrm{mg} / \mathrm{lit}$., $20 \mathrm{mg} / \mathrm{lit}$., $30 \mathrm{mg} / \mathrm{lit}$., $40 \mathrm{mg} / \mathrm{lit}$, $50 \mathrm{mg} / \mathrm{lit}$ of $\mathrm{MgSO}_{4}$ nano particles respectively Table. 5 . 
The magnesium value of the raw effluent was $520 \mathrm{mg} / \mathrm{lit}$ and decrease to $462 \mathrm{mg} / \mathrm{lit}, 448 \mathrm{mg} /$ lit, $422 \mathrm{mg} / \mathrm{lit}, 409 \mathrm{mg} / \mathrm{lit}$, and $399 \mathrm{mg} / \mathrm{lit}$ with the addition of $10 \mathrm{mg} /$ lit., $20 \mathrm{mg} / \mathrm{lit}$., $30 \mathrm{mg} / \mathrm{lit}$., $40 \mathrm{mg} / \mathrm{lit}$, $50 \mathrm{mg} / \mathrm{lit}$ of $\mathrm{MgSO}_{4}$ nano particles respectively Table. 5 .

The phosphate value of the raw effluent was $0.28 \mathrm{mg} / \mathrm{lit}$ and decrease to $0.22 \mathrm{mg} / \mathrm{lit}, 0.20$ $\mathrm{mg} / \mathrm{lit}, 0.17 \mathrm{mg} / \mathrm{lit}, 0.15 \mathrm{mg} / \mathrm{lit}$, and $0.13 \mathrm{mg} / \mathrm{lit}$ with the addition of $10 \mathrm{mg} / \mathrm{lit}$., $20 \mathrm{mg} / \mathrm{lit}$, $30 \mathrm{mg} / \mathrm{lit}$., 40 $\mathrm{mg} / \mathrm{lit}, 50 \mathrm{mg} / \mathrm{lit}$ of $\mathrm{MgSO}_{4}$ nano particles respectively Table. 5.

The sodium value of the raw effluent was $490 \mathrm{mg} / \mathrm{lit}$ and decrease to $473 \mathrm{mg} / \mathrm{lit}, 471 \mathrm{mg} / \mathrm{lit}$, $467 \mathrm{mg} / \mathrm{lit}, 463 \mathrm{mg} / \mathrm{lit}$, and $458 \mathrm{mg} / \mathrm{lit}$ with the addition of $10 \mathrm{mg} / \mathrm{lit}$., $20 \mathrm{mg} / \mathrm{lit}$., $30 \mathrm{mg} / \mathrm{lit}$., $40 \mathrm{mg} / \mathrm{lit}, 50 \mathrm{mg} / \mathrm{lit}$ of $\mathrm{MgSO}_{4}$ nano particles respectively Table. 5 .

The potassium value of the raw effluent was $17 \mathrm{mg} / \mathrm{lit}$ and decrease to $13 \mathrm{mg} / \mathrm{lit}, 12 \mathrm{mg} / \mathrm{lit}$, $11 \mathrm{mg} / \mathrm{lit}, 9 \mathrm{mg} / \mathrm{lit}$, and $7 \mathrm{mg} / \mathrm{lit}$ with the addition of $10 \mathrm{mg} /$ lit., $20 \mathrm{mg} /$ /it., $30 \mathrm{mg} / \mathrm{lit}$., $40 \mathrm{mg} / \mathrm{lit}, 50 \mathrm{mg} / \mathrm{lit}$ of $\mathrm{MgSO}_{4}$ nano particles respectively Table. 5.

The nitrate value of the raw effluent was $2.00 \mathrm{mg} / \mathrm{lit}$ and decrease to $1.90 \mathrm{mg} / \mathrm{lit}, 1.85 \mathrm{mg} / \mathrm{lit}$, $1.81 \mathrm{mg} / \mathrm{lit}, 1.77 \mathrm{mg} / \mathrm{lit}$, and $1.74 \mathrm{mg} / \mathrm{lit}$ with the addition of $10 \mathrm{mg} / \mathrm{lit}$, $20 \mathrm{mg} / \mathrm{lit}$., $30 \mathrm{mg} / \mathrm{lit}$., $40 \mathrm{mg} / \mathrm{lit}$, $50 \mathrm{mg} / \mathrm{lit}$ of $\mathrm{MgSO}_{4}$ nano particles respectively Table. 5.

\section{Effect of $\mathrm{CuSO}_{4} \cdot 5 \mathrm{H}_{2} \mathrm{O}$ nano particles on dye combined waste water}

The $\mathrm{pH}$ of the raw effluent was 10.2 It was decreases to $9.7,9.5,9.4,9.2$ and 8.9 with addition of $10 \mathrm{mg} / \mathrm{lit}$., $20 \mathrm{mg} / \mathrm{lit}$., $30 \mathrm{mg} / \mathrm{lit}$., $40 \mathrm{mg} / \mathrm{lit}, 50 \mathrm{mg} / \mathrm{lit}$ of $\mathrm{CuSO}_{4} \cdot 5 \mathrm{H}_{2} \mathrm{O}$ nano particles respectively Table. 6 due to the basic nature of the coagulant. The increase of $\mathrm{pH}$ might due to the release of the hydroxide ions in the complexes depict the change of $\mathrm{pH}$ as a function of the coagulant concentration.

The total dissolved solid value of the raw effluent was $14,692 \mathrm{mg} / \mathrm{lit}$ and decrease to 12,300 $\mathrm{mg} / \mathrm{lit}, 12,000 \mathrm{mg} / \mathrm{lit}, 11,700,11,100 \mathrm{mg} / \mathrm{lit}$ and $10,400 \mathrm{mg} /$ lit with the addition of $10 \mathrm{mg} / \mathrm{lit}$., $20 \mathrm{mg} /$ lit., $30 \mathrm{mg} /$ lit., $40 \mathrm{mg} / \mathrm{lit}, 50 \mathrm{mg} / \mathrm{lit}$ of $\mathrm{CuSO}_{4} \cdot 5 \mathrm{H}_{2} \mathrm{O}$ nano particles respectively Table-6. It was observed that there was reduction of TDS was imparted by the $\mathrm{CuSO}_{4} \cdot 5 \mathrm{H}_{2} \mathrm{O}$ nano particles added. The main objective of chemical treatment is to remove colloids carried by the effluent. Since colloidal particles are charged particles, and these charged particle trapped using complexes carrying opposite

Table. 5: Characterization of Dye effluent with $\mathrm{MgSO}_{4}$ nano particle

\begin{tabular}{|c|c|c|c|c|c|c|c|c|}
\hline S.NO & Parameters & Unit & Raw Sample & $10 \mathrm{Mg} / \mathrm{L}$ & $20 \mathrm{Mg} / \mathrm{L}$ & $30 \mathrm{Mg} / \mathrm{L}$ & $40 \mathrm{Mg} / \mathrm{L}$ & $50 \mathrm{Mg} / \mathrm{L}$ \\
\hline 1. & $\mathrm{pH}$ at $25^{\circ} \mathrm{C}$ & Number & 8.5 & 8.6 & 8.8 & 8.8 & 8.9 & 9.4 \\
\hline 2. & $\begin{array}{l}\text { Total Dissolved } \\
\text { solids at } 180^{\circ} \mathrm{C}\end{array}$ & $\mathrm{Mg} / \mathrm{L}$ & 15,216 & 8520 & 6490 & 6471 & 6432 & 6330 \\
\hline 3. & Chlorides as $\mathrm{Cl}$ & $\mathrm{Mg} / \mathrm{L}$ & 3500 & 1194 & 1183 & 1143 & 1168 & 1127 \\
\hline 4. & Sulphide as $\mathrm{SO}_{4}^{2-}$ & $\mathrm{Mg} / \mathrm{L}$ & 1900 & 1397 & 1351 & 1297 & 1275 & 1243 \\
\hline 5. & $\begin{array}{l}\text { BOD (at } 27^{\circ} \mathrm{C} \\
\text { for } 3 \text { days) }\end{array}$ & Mg/L & 600 & 324 & 312 & 298 & 286 & 273 \\
\hline 6. & COD & $\mathrm{Mg} / \mathrm{L}$ & 3400 & 2198 & 2143 & 2083 & 2041 & 2005 \\
\hline 7. & Alkalinity & $\mathrm{Mg} / \mathrm{L}$ & 7000 & 2630 & 2542 & 2367 & 2277 & 2168 \\
\hline 8. & Total hardness & $\mathrm{Mg} / \mathrm{L}$ & 4500 & 1414 & 1383 & 1375 & 1366 & 1361 \\
\hline 9. & Calcium & $\mathrm{Mg} / \mathrm{L}$ & 3000 & 926 & 904 & 891 & 876 & 863 \\
\hline 10. & Magnesium & $\mathrm{Mg} / \mathrm{L}$ & 900 & 462 & 448 & 422 & 409 & 399 \\
\hline 11. & Sulphide & $\mathrm{Mg} / \mathrm{L}$ & 27 & 11 & 8 & 6 & 5 & 3 \\
\hline 12. & Phosphate & $\mathrm{Mg} / \mathrm{L}$ & 1.59 & 0.22 & 0.20 & 0.17 & 0.15 & 0.13 \\
\hline 13. & Sodium & $\mathrm{Mg} / \mathrm{L}$ & 800 & 473 & 471 & 467 & 463 & 458 \\
\hline 14. & Potassium & $\mathrm{Mg} / \mathrm{L}$ & 30 & 13 & 12 & 11 & 9 & 7 \\
\hline 15. & Nitrate & $\mathrm{Mg} / \mathrm{L}$ & 5.10 & 1.90 & 1.85 & 1.81 & 1.77 & 1.74 \\
\hline
\end{tabular}


charges in order to form flock and create density gradient between liquid and suspended solid phase (to reduce zeta potential of suspended colloidal particles).

Chloride value of the raw effluent was 2680 $\mathrm{mg} / \mathrm{lit}$. It was decreases to $2400 \mathrm{mg} / \mathrm{lit}, 2325 \mathrm{mg} / \mathrm{lit}$, $2240 \mathrm{mg} / \mathrm{lit}$., $2180 \mathrm{mg} / \mathrm{lit}$, and $2100 \mathrm{mg} / \mathrm{lit}$ with the addition of $10 \mathrm{mg} /$ lit., $20 \mathrm{mg} / \mathrm{lit}$., $30 \mathrm{mg} / \mathrm{lit}$., $40 \mathrm{mg} / \mathrm{lit}$, and $50 \mathrm{mg} / \mathrm{lit}$ of $\mathrm{CuSO}_{4} \cdot 5 \mathrm{H}_{2} \mathrm{O}$ nano particles respectively Table. 6 . The reduction in the chloride value might be due to the replacement of chloride by per chlorate ions in plain sedimentation.

Sulphate value of the raw effluent was $4418 \mathrm{mg} / \mathrm{lit}$. It was decreases to $4239 \mathrm{mg} / \mathrm{lit}, 4180$ $\mathrm{mg} / \mathrm{lit}, 3972 \mathrm{mg} / \mathrm{lit}, 3680 \mathrm{mg} / \mathrm{lit}$ and $3379 \mathrm{mg} / \mathrm{lit}$. with the addition of $10 \mathrm{mg} /$ lit., $20 \mathrm{mg} / \mathrm{lit}$., $30 \mathrm{mg} / \mathrm{lit}$., 40 $\mathrm{mg} / \mathrm{lit}, 50 \mathrm{mg} / \mathrm{lit}$ of $\mathrm{CuSO}_{4} .5 \mathrm{H}_{2} \mathrm{O}$ nano particles respectively Table. 6 . The reduction in the Sulphate value might be due to the oxidation of Sulphate form into elementary Sulphur, which formed flocculation and undergo plain sedimentation.

The BOD of the raw effluent was $486 \mathrm{mg} / \mathrm{lit}$ and decreases to $430 \mathrm{mg} / \mathrm{lit}, 425 \mathrm{mg} / \mathrm{lit}, 415 \mathrm{mg} / \mathrm{lit}$, $405 \mathrm{mg} / \mathrm{lit}$, and $400 \mathrm{mg} / \mathrm{lit}$ with the addition of 10 $\mathrm{mg} / \mathrm{lit}$, $20 \mathrm{mg} / \mathrm{lit}$., $30 \mathrm{mg} / \mathrm{lit}$., $40 \mathrm{mg} / \mathrm{lit}, 50 \mathrm{mg} / \mathrm{lit}$ of $\mathrm{CuSO}_{4} \cdot 5 \mathrm{H}_{2} \mathrm{O}$ nano particles respectively Table. 6 . The decrease in BOD might be due to coagulating effect of the complex with bio organic compounds. It is evident that heavy metals are toxic to aquatic microorganisms beyond certain concentration.

The COD value of the raw effluent was $3560 \mathrm{mg} / \mathrm{lit}$ and decrease to $3200 \mathrm{mg} / \mathrm{lit}, 3120 \mathrm{mg} /$ lit, $3040 \mathrm{mg} / \mathrm{lit}, 2970 \mathrm{mg} / \mathrm{lit}$, and $2880 \mathrm{mg} / \mathrm{lit}$ with the addition of $10 \mathrm{mg} / \mathrm{lit}$, $20 \mathrm{mg} / \mathrm{lit}$., $30 \mathrm{mg} / \mathrm{lit}$., $40 \mathrm{mg} /$ lit, $50 \mathrm{mg} / \mathrm{lit}$ of $\mathrm{CuSO}_{4} .5 \mathrm{H}_{2} \mathrm{O}$ nano particles respectively Table. 6 . This reduction in COD might be due to nitrogenous increment in waste water by addition of dosed complexes.

The Alkalinity of the raw effluent was 6900 $\mathrm{mg} / \mathrm{lit}$ and decrease to $6200 \mathrm{mg} / \mathrm{lit}, 6175 \mathrm{mg} / \mathrm{lit}, 6150$ $\mathrm{mg} / \mathrm{lit}, 6120 \mathrm{mg} / \mathrm{lit}$, and $6100 \mathrm{mg} / \mathrm{lit}$ with the addition of $10 \mathrm{mg} / \mathrm{lit}$., $20 \mathrm{mg} / \mathrm{lit}$., $30 \mathrm{mg} / \mathrm{lit}$., $40 \mathrm{mg} / \mathrm{lit}, 50 \mathrm{mg} / \mathrm{lit}$ of $\mathrm{CuSO}_{4} \cdot 5 \mathrm{H}_{2}$ Onano particles respectively Table. 6 .
The total hardness of the raw effluent was $7000 \mathrm{mg} / \mathrm{lit}$ and decrease to $6500 \mathrm{mg} / \mathrm{lit}, 6460 \mathrm{mg} /$ lit, $6400 \mathrm{mg} / \mathrm{lit}, 6340 \mathrm{mg} / \mathrm{lit}$, and $6300 \mathrm{mg} / \mathrm{lit}$ with the addition of $10 \mathrm{mg} / \mathrm{lit}$., $20 \mathrm{mg} / \mathrm{lit}$., $30 \mathrm{mg} / \mathrm{lit}$., $40 \mathrm{mg} / \mathrm{lit}$, $50 \mathrm{mg} / \mathrm{lit}$ of $\mathrm{CuSO}_{4} \cdot 5 \mathrm{H}_{2} \mathrm{O}$ nano particles respectively Table. 6.

Calcium value of the raw effluent was 2100 $\mathrm{mg} / \mathrm{lit}$ and decrease to $1400 \mathrm{mg} / \mathrm{lit}, 1384 \mathrm{mg} / \mathrm{lit}, 1372$ $\mathrm{mg} / \mathrm{lit}, 1367 \mathrm{mg} / \mathrm{lit}$, and $1362 \mathrm{mg} / \mathrm{lit}$ with the addition of $10 \mathrm{mg} / \mathrm{lit}$., $20 \mathrm{mg} / \mathrm{lit}$., $30 \mathrm{mg} / \mathrm{lit}$., $40 \mathrm{mg} / \mathrm{lit}, 50 \mathrm{mg} / \mathrm{lit}$ of $\mathrm{CuSO}_{4} \cdot 5 \mathrm{H}_{2}$ Onano particles respectively Table. 6 .

The Magnesium value of the raw effluent was $840 \mathrm{mg} / \mathrm{lit}$ and decrease to $729 \mathrm{mg} / \mathrm{lit}, 717 \mathrm{mg} /$ lit, $702 \mathrm{mg} / \mathrm{lit}, 693 \mathrm{mg} / \mathrm{lit}$, and $680 \mathrm{mg} / \mathrm{lit}$ with the addition of $10 \mathrm{mg} / \mathrm{lit}$., $20 \mathrm{mg} / \mathrm{lit}$., $30 \mathrm{mg} / \mathrm{lit}$., $40 \mathrm{mg} / \mathrm{lit}$, $50 \mathrm{mg} / \mathrm{lit}$ of $\mathrm{CuSO}_{4} \cdot 5 \mathrm{H}_{2}$ Onano particles respectively Table. 6.

Sulphide value of the raw effluent was 18 $\mathrm{mg} / \mathrm{lit}$ and decrease to $12 \mathrm{mg} / \mathrm{lit}, 11 \mathrm{mg} / \mathrm{lit}, 10 \mathrm{mg} / \mathrm{lit}$, $9 \mathrm{mg} / \mathrm{lit}$, and $8 \mathrm{mg} / \mathrm{lit}$ with the addition of $10 \mathrm{mg} / \mathrm{lit}$., $20 \mathrm{mg} / \mathrm{lit}$, $30 \mathrm{mg} / \mathrm{lit}$., $40 \mathrm{mg} / \mathrm{lit}, 50 \mathrm{mg} / \mathrm{lit}$ of $\mathrm{CuSO}_{4} \cdot 5 \mathrm{H}_{2}$ On ano particles respectivelyTable. 6 .

Phosphate value of the raw effluent was $0.78 \mathrm{mg} / \mathrm{lit}$ and decrease to $0.62 \mathrm{mg} / \mathrm{lit}, 0.58 \mathrm{mg} / \mathrm{lit}$, $0.47 \mathrm{mg} / \mathrm{lit}, 0.35 \mathrm{mg} / \mathrm{lit}$, and $0.33 \mathrm{mg} / \mathrm{lit}$ with the addition of $10 \mathrm{mg} / \mathrm{lit}$., $20 \mathrm{mg} / \mathrm{lit}$., $30 \mathrm{mg} / \mathrm{lit}$., $40 \mathrm{mg} / \mathrm{lit}$, $50 \mathrm{mg} / \mathrm{lit}$ of $\mathrm{CuSO}_{4} \cdot 5 \mathrm{H}_{2}$ Onano particles respectively Table. 6.

Sodium value of the raw effluent was 980 $\mathrm{mg} / \mathrm{lit}$ and decrease to $900 \mathrm{mg} / \mathrm{lit}, 885 \mathrm{mg} / \mathrm{lit}, 872$ $\mathrm{mg} / \mathrm{lit}, 861 \mathrm{mg} / \mathrm{lit}$, and $840 \mathrm{mg} / \mathrm{lit}$ with the addition of $10 \mathrm{mg} /$ /it., $20 \mathrm{mg} / \mathrm{lit}$., $30 \mathrm{mg} / \mathrm{lit}$., $40 \mathrm{mg} / \mathrm{lit}, 50 \mathrm{mg} / \mathrm{lit}$ of $\mathrm{CuSO}_{4} \cdot 5 \mathrm{H}_{2}$ Onano particles respectively Table. 6 .

Potassium value of the raw effluent was $32 \mathrm{mg} / \mathrm{lit}$ and decrease to $25 \mathrm{mg} / \mathrm{lit}, 17 \mathrm{mg} / \mathrm{lit}, 14$ $\mathrm{mg} / \mathrm{lit}, 13 \mathrm{mg} / \mathrm{lit}$, and $11 \mathrm{mg} / \mathrm{lit}$ with the addition of 10 $\mathrm{mg} / \mathrm{lit}$, $20 \mathrm{mg} / \mathrm{lit}$., $30 \mathrm{mg} / \mathrm{lit}$., $40 \mathrm{mg} / \mathrm{lit}, 50 \mathrm{mg} / \mathrm{lit}$ of $\mathrm{CuSO}_{4} \cdot 5 \mathrm{H}_{2}$ Onano particles respectively Table. 6 .

Nitrate value of the raw effluent was 3.03 $\mathrm{mg} / \mathrm{lit}$ and decrease to $2.37 \mathrm{mg} / \mathrm{lit}, 2.12 \mathrm{mg} / \mathrm{lit}, 1.82$ $\mathrm{mg} / \mathrm{lit}, 1.74 \mathrm{mg} / \mathrm{lit}$, and $1.60 \mathrm{mg} / \mathrm{lit}$ with the addition of $10 \mathrm{mg} /$ /it., $20 \mathrm{mg} / \mathrm{lit}$, $30 \mathrm{mg} / \mathrm{lit}$., $40 \mathrm{mg} / \mathrm{lit}, 50 \mathrm{mg} / \mathrm{lit}$ of $\mathrm{CuSO}_{4} \cdot 5 \mathrm{H}_{2} \mathrm{O}$ nano particles respectively Table. 6 . 
The $\mathrm{pH}$ of the raw effluent was 8.5. It was increased to $8.5,8.8,9.0,9.2$, and 9.8 with addition of $10 \mathrm{mg} / \mathrm{lit}$., $20 \mathrm{mg} / \mathrm{lit}$., $30 \mathrm{mg} / \mathrm{lit}$., $40 \mathrm{mg} / \mathrm{lit}, 50 \mathrm{mg} / \mathrm{lit}$ of nano adsorbent of $\mathrm{FeSO}_{4} .7 \mathrm{H}_{2} \mathrm{O}$ respectively Table. 7 due to the basic nature of the coagulant. The increase of $\mathrm{pH}$ might due to the release of the hydroxide ions in the complexes depict the change of $\mathrm{pH}$ as a function of the coagulant concentration.

The total dissolved solid value of the raw effluent was 15,216 and decrease to $13,172 \mathrm{mg} / \mathrm{l}$, $13,041 \mathrm{mg} / \mathrm{l}, 12,840 \mathrm{mg} / \mathrm{l}, 12,520 \mathrm{mg} / \mathrm{l}$ and 12,163 $\mathrm{mg} / \mathrm{lit}$ with the addition of $10 \mathrm{mg} / \mathrm{lit}$., $20 \mathrm{mg} / \mathrm{lit}$., 30 $\mathrm{mg} / \mathrm{lit} ., \quad 40 \mathrm{mg} / \mathrm{lit}, 50 \mathrm{mg} / \mathrm{lit}$ of nano adsorbent of $\mathrm{FeSO}_{4} .7 \mathrm{H}_{2} \mathrm{O}$ respectively Table. 7 . It was observed that there was reduction of TDS was imparted by the chemicals added. The main objective of chemical treatment is to remove colloids carried by the effluent. Since colloidal particles are charged particles, and these charged particle trapped using complexes carrying opposite charges in order to form flock and create density gradient between liquid and suspended solid phase (to reduce zeta potential of suspended colloidal particles).

Chloride value of the raw effluent was 3500 $\mathrm{mg} / \mathrm{lit}$. It was decreases to $2821 \mathrm{mg} / \mathrm{lit}, 2735 \mathrm{mg} / \mathrm{lit}$, $2613 \mathrm{mg} / \mathrm{lit}$, $2521 \mathrm{mg} / \mathrm{lit}$, and $2405 \mathrm{mg} / \mathrm{lit}$ with the addition of $10 \mathrm{mg} / \mathrm{lit}$., $20 \mathrm{mg} / \mathrm{lit}$., $30 \mathrm{mg} / \mathrm{lit}$., $40 \mathrm{mg} / \mathrm{lit}$, and $50 \mathrm{mg} / \mathrm{lit}$. of nano adsorbent of $\mathrm{FeSO}_{4} \cdot 7 \mathrm{H}_{2} \mathrm{O}$ respectively Table. 7 . The reduction in the chloride value might be due to the replacement of chloride by perchlorate ions in plain sedimentation.

Sulphate value of the raw effluent was $1900 \mathrm{mg} / \mathrm{lit}$. It was decreases to $1725 \mathrm{mg} / \mathrm{lit}, 1707$ $\mathrm{mg} / \mathrm{lit}, 1696 \mathrm{mg} / \mathrm{lit}, 1670 \mathrm{mg} / \mathrm{lit}$ and $1649 \mathrm{mg} / \mathrm{lit}$. with the addition of $10 \mathrm{mg} / \mathrm{lit}$., $20 \mathrm{mg} / \mathrm{lit}$., $30 \mathrm{mg} / \mathrm{lit}$., 40 $\mathrm{mg} / \mathrm{lit}, 50 \mathrm{mg} / \mathrm{lit}$ of nano adsorbent of $\mathrm{FeSO}_{4} \cdot 7 \mathrm{H}_{2} \mathrm{O}$ respectively Table. 7 . The reduction in the sulphate value might be due to the oxidation of sulphate form into elementary sulphur, which formed flocculation and undergo plain sedimentation.

The BOD of the raw effluent was $600 \mathrm{mg} /$ lit and decreases to $492 \mathrm{mg} / \mathrm{lit}, 450 \mathrm{mg} / \mathrm{lit}, 430 \mathrm{mg} /$ lit, $417 \mathrm{mg} / \mathrm{lit}$, and $402 \mathrm{mg} / \mathrm{lit}$ with the addition of 10 mg/lit., 20 mg/lit., 30 mg/lit., 40 mg/lit,50 mg/lit of nano adsorbent of $\mathrm{FeSO}_{4} \cdot 7 \mathrm{H}_{2} \mathrm{O}$ respectively Table.
7. The decrease in BOD might be due to coagulating effect of the complex with bio organic compounds. It is evident that heavy metals are toxic to aquatic microorganisms beyond certain concentration.

The COD value of the raw effluent was $3400 \mathrm{mg} / \mathrm{lit}$ and decrease to $2688 \mathrm{mg} / \mathrm{lit}, 2640 \mathrm{mg} /$ lit, $2616 \mathrm{mg} / \mathrm{lit}, 2593 \mathrm{mg} / \mathrm{lit}$, and $2574 \mathrm{mg} / \mathrm{lit}$ with the addition of $10 \mathrm{mg} / \mathrm{lit}$., $20 \mathrm{mg} / \mathrm{lit}$., $30 \mathrm{mg} / \mathrm{lit} ., 40 \mathrm{mg} /$ lit,50 mg/lit. of complexes respectively Table. 7 . This reduction in COD might be due to nitrogenous increment in waste water by addition of dosed nano adsorbent of $\mathrm{FeSO}_{4} \cdot 7 \mathrm{H}_{2} \mathrm{O}$.

Alkalinity of the raw effluent was $7000 \mathrm{mg} /$ lit and decrease to $6132 \mathrm{mg} / \mathrm{lit}, 6109 \mathrm{mg} / \mathrm{lit}, 6094$ $\mathrm{mg} / \mathrm{lit}, 6079 \mathrm{mg} / \mathrm{lit}$, and $6050 \mathrm{mg} / \mathrm{lit}$ with the addition of $10 \mathrm{mg} / \mathrm{lit}$., $20 \mathrm{mg} / \mathrm{lit}$., $30 \mathrm{mg} / \mathrm{lit}$., $40 \mathrm{mg} / \mathrm{lit}, 50 \mathrm{mg} / \mathrm{lit}$ of nano adsorbent of $\mathrm{FeSO}_{4} \cdot 7 \mathrm{H}_{2} \mathrm{O}$ respectively Table. 7.

The total hardness of the raw effluent was $4500 \mathrm{mg} / \mathrm{lit}$ and decrease to $3725 \mathrm{mg} / \mathrm{lit}, 3520 \mathrm{mg} /$ lit, $3415 \mathrm{mg} / \mathrm{lit}, 3211 \mathrm{mg} / \mathrm{lit}$, and $3113 \mathrm{mg} / \mathrm{lit}$ with the addition of $10 \mathrm{mg} /$ lit., $20 \mathrm{mg} / \mathrm{lit}$., $30 \mathrm{mg} / \mathrm{lit}$., $40 \mathrm{mg} / \mathrm{lit}$, $50 \mathrm{mg} / \mathrm{lit}$ of nano adsorbent of $\mathrm{FeSO}_{4} \cdot 7 \mathrm{H}_{2} \mathrm{O}$ respectively Table. 7 .

Calcium value of the raw effluent was 3000 $\mathrm{mg} / \mathrm{lit}$ and decrease to $2310 \mathrm{mg} / \mathrm{lit}, 2262 \mathrm{mg} / \mathrm{lit}, 2174$ $\mathrm{mg} / \mathrm{lit}, 2033 \mathrm{mg} / \mathrm{lit}$, and $1983 \mathrm{mg} / \mathrm{lit}$ with the addition of $10 \mathrm{mg} / \mathrm{lit}$., $20 \mathrm{mg} / \mathrm{lit}$., $30 \mathrm{mg} / \mathrm{lit}$., $40 \mathrm{mg} / \mathrm{lit}, 50 \mathrm{mg} /$ lit of nano adsorbent of $\mathrm{FeSO}_{4} \cdot 7 \mathrm{H}_{2} \mathrm{O}$ respectively Table. 7 .

Magnesium value of the raw effluent was $900 \mathrm{mg} / \mathrm{lit}$ and decrease to $834 \mathrm{mg} / \mathrm{lit}, 815 \mathrm{mg} / \mathrm{lit}$, $793 \mathrm{mg} / \mathrm{lit}, 784 \mathrm{mg} / \mathrm{lit}$, and $762 \mathrm{mg} / \mathrm{lit}$ with the addition of $10 \mathrm{mg} / \mathrm{lit}$., $20 \mathrm{mg} / \mathrm{lit}$., $30 \mathrm{mg} / \mathrm{lit}$., $40 \mathrm{mg} / \mathrm{lit}$, $50 \mathrm{mg} / \mathrm{lit}$ of nano adsorbent of $\mathrm{FeSO}_{4} \cdot 7 \mathrm{H}_{2} \mathrm{O}$ respectively Table. 7 .

Sulphide value of the raw effluent was 27 $\mathrm{mg} / \mathrm{lit}$ and decrease to $19 \mathrm{mg} / \mathrm{lit}, 15 \mathrm{mg} / \mathrm{lit}, 13 \mathrm{mg} / \mathrm{lit}$, $10 \mathrm{mg} / \mathrm{lit}$, and $9 \mathrm{mg} / \mathrm{lit}$ with the addition of $10 \mathrm{mg} / \mathrm{lit}$., $20 \mathrm{mg} / \mathrm{lit}$., $30 \mathrm{mg} / \mathrm{lit}$., $40 \mathrm{mg} / \mathrm{lit}, 50 \mathrm{mg} / \mathrm{lit}$ of nano adsorbent of $\mathrm{FeSO}_{4} \cdot 7 \mathrm{H}_{2} \mathrm{O}$ respectively Table. 7 . 
Phosphate value of the raw effluent was $1.59 \mathrm{mg} / \mathrm{lit}$ and decrease to $1.03 \mathrm{mg} / \mathrm{lit}, 0.95 \mathrm{mg} / \mathrm{lit}$, $0.81 \mathrm{mg} / \mathrm{lit}, 0.62 \mathrm{mg} / \mathrm{lit}$, and $0.53 \mathrm{mg} / \mathrm{lit}$ with the addition of $10 \mathrm{mg} /$ lit., $20 \mathrm{mg} / \mathrm{lit}$., $30 \mathrm{mg} / \mathrm{lit}$., $40 \mathrm{mg} / \mathrm{lit}$, $50 \mathrm{mg} / \mathrm{lit}$ of nano adsorbent of $\mathrm{FeSO}_{4} \cdot 7 \mathrm{H}_{2} \mathrm{O}$ respectively Table. 7 .
Sodium value of the raw effluent was 800 $\mathrm{mg} / \mathrm{lit}$ and decrease to $713 \mathrm{mg} / \mathrm{lit}, 685 \mathrm{mg} / \mathrm{lit}, 661$ $\mathrm{mg} / \mathrm{lit}, 632 \mathrm{mg} / \mathrm{lit}$, and $614 \mathrm{mg} / \mathrm{lit}$ with the addition of $10 \mathrm{mg} / \mathrm{lit}$., $20 \mathrm{mg} / \mathrm{lit}$., $30 \mathrm{mg} / \mathrm{lit}$., $40 \mathrm{mg} / \mathrm{lit}, 50 \mathrm{mg} / \mathrm{lit}$ of nano adsorbent of $\mathrm{FeSO}_{4} \cdot 7 \mathrm{H}_{2} \mathrm{O}$ respectively Table. 7 .

Table.6: Characterization of Dye effluent with $\mathrm{CuSO}_{4} \cdot 5 \mathrm{H}_{2} \mathrm{O}$ nano particles

\begin{tabular}{|c|c|c|c|c|c|c|c|c|}
\hline S.NO & Parameters & Unit & Raw Sample & $10 \mathrm{mg} / \mathrm{L}$ & $20 \mathrm{mg} / \mathrm{L}$ & $30 \mathrm{mg} / \mathrm{L}$ & $40 \mathrm{mg} / \mathrm{L}$ & $50 \mathrm{mg} / \mathrm{L}$ \\
\hline 1. & $\mathrm{pH}$ at $25^{\circ} \mathrm{C}$ & Number & 8.5 & 8.5 & 8.8 & 9.0 & 9.2 & 9.8 \\
\hline 2. & $\begin{array}{l}\text { Total Dissolved } \\
\text { solids at } 180^{\circ} \mathrm{C}\end{array}$ & $\mathrm{Mg} / \mathrm{L}$ & 15,216 & 12,300 & 12,000 & 11,700 & 11,100 & 10,400 \\
\hline 3. & Chlorides as $\mathrm{Cl}$ & $\mathrm{Mg} / \mathrm{L}$ & 3500 & 2400 & 2325 & 2240 & 2180 & 2100 \\
\hline 4. & Sulphide as $\mathrm{SO}_{4}$ & $\mathrm{Mg} / \mathrm{L}$ & 1900 & 4239 & 4180 & 3972 & 3680 & 3379 \\
\hline 5. & $\begin{array}{l}\mathrm{BOD} \text { (at } 27^{\circ} \mathrm{C} \\
\text { for } 3 \text { days) }\end{array}$ & $\mathrm{Mg} / \mathrm{L}$ & 600 & 430 & 425 & 415 & 405 & 400 \\
\hline 6. & COD & $\mathrm{Mg} / \mathrm{L}$ & 3400 & 3200 & 3120 & 3040 & 2970 & 2880 \\
\hline 7. & Alkalinity & $\mathrm{Mg} / \mathrm{L}$ & 7000 & 6200 & 6175 & 6150 & 6120 & 6100 \\
\hline 8. & Total hardness & $\mathrm{Mg} / \mathrm{L}$ & 4500 & 6500 & 6460 & 6400 & 6340 & 6300 \\
\hline 9. & Calcium & $\mathrm{Mg} / \mathrm{L}$ & 3000 & 1400 & 1384 & 1372 & 1367 & 1362 \\
\hline 10. & Magnesium & $\mathrm{Mg} / \mathrm{L}$ & 900 & 729 & 717 & 702 & 693 & 680 \\
\hline 11. & Sulphide & $\mathrm{Mg} / \mathrm{L}$ & 27 & 12 & 11 & 10 & 9 & 8 \\
\hline 12. & Phosphate & $\mathrm{Mg} / \mathrm{L}$ & 1.59 & 0.62 & 0.58 & 0.47 & 0.35 & 0.33 \\
\hline 13. & Sodium & $\mathrm{Mg} / \mathrm{L}$ & 800 & 900 & 885 & 872 & 861 & 840 \\
\hline 14. & Potassium & $\mathrm{Mg} / \mathrm{L}$ & 30 & 25 & 17 & 14 & 13 & 11 \\
\hline 15. & Nitrate & $\mathrm{Mg} / \mathrm{L}$ & 5.10 & 2.37 & 2.12 & 1.82 & 1.74 & 1.60 \\
\hline
\end{tabular}

Table. 7: Characterization of Dye effluent with $\mathrm{FeSO}_{4} \cdot 7 \mathrm{H}_{2} \mathrm{O}$ nano particles

\begin{tabular}{|c|c|c|c|c|c|c|c|c|}
\hline S.NO & Parameters & Unit & Raw Sample & $10 \mathrm{Mg} / \mathrm{l}$ & 20 Mg/l & $30 \mathrm{Mg} / \mathrm{l}$ & $40 \mathrm{Mg} / \mathrm{l}$ & $50 \mathrm{Mg} /$ \\
\hline 1. & $\mathrm{pH}$ at $25^{\circ} \mathrm{C}$ & Number & 8.5 & 8.8 & 9.0 & 9.1 & 9.1 & 9.4 \\
\hline 2. & $\begin{array}{l}\text { Total Dissolved } \\
\text { solids at } 180^{\circ} \mathrm{C}\end{array}$ & $\mathrm{Mg} / \mathrm{L}$ & 15,216 & 13,172 & 13,041 & 12,840 & 12,520 & 12,163 \\
\hline 3. & Chlorides as $\mathrm{Cl}$ & $\mathrm{Mg} / \mathrm{L}$ & 3500 & 2821 & 2735 & 2613 & 2521 & 2405 \\
\hline 4. & Sulphide as $\mathrm{SO}_{4}$ & $\mathrm{Mg} / \mathrm{L}$ & 1900 & 1725 & 1707 & 1696 & 1670 & 1649 \\
\hline 5. & $\begin{array}{l}\text { BOD (at } 27^{\circ} \mathrm{C} \\
\text { for } 3 \text { days) }\end{array}$ & $\mathrm{Mg} / \mathrm{L}$ & 600 & 492 & 450 & 43017 & 402 & \\
\hline 6. & COD & $\mathrm{Mg} / \mathrm{L}$ & 3400 & 2688 & 2640 & 2616 & 2593 & 2574 \\
\hline 7. & Alkalinity & $\mathrm{Mg} / \mathrm{L}$ & 7000 & 6132 & 6109 & 6094 & 6079 & 6050 \\
\hline 8. & Total hardness & $\mathrm{Mg} / \mathrm{L}$ & 4500 & 3725 & 3520 & 3415 & 3211 & 3113 \\
\hline 9. & Calcium & $\mathrm{Mg} / \mathrm{L}$ & 3000 & 2310 & 2262 & 2174 & 2033 & 1983 \\
\hline 10. & Magnesium & $\mathrm{Mg} / \mathrm{L}$ & 900 & 834 & 815 & 793 & 784 & 762 \\
\hline 11. & Sulphide & $\mathrm{Mg} / \mathrm{L}$ & 27 & 19 & 15 & 13 & 10 & 9 \\
\hline 12. & Phosphate & $\mathrm{Mg} / \mathrm{L}$ & 1.59 & 1.03 & 0.95 & 0.81 & 0.62 & 0.614 \\
\hline 13. & Sodium & $\mathrm{Mg} / \mathrm{L}$ & 800 & 713 & 685 & 661 & 632 & 614 \\
\hline 14. & Potassium & $\mathrm{Mg} / \mathrm{L}$ & 30 & 26 & 23 & 17 & 15 & 12 \\
\hline 15. & Nitrate & $\mathrm{Mg} / \mathrm{L}$ & 5.10 & 4.13 & 3.87 & 3.65 & 3.41 & 3.12 \\
\hline
\end{tabular}


Potassium value of the raw effluent was $30 \mathrm{mg} / \mathrm{lit}$ and decrease to $26 \mathrm{mg} / \mathrm{lit}, 23 \mathrm{mg} / \mathrm{lit}, 17$ $\mathrm{mg} / \mathrm{lit}, 15 \mathrm{mg} / \mathrm{lit}$, and $12 \mathrm{mg} / \mathrm{lit}$ with the addition of $10 \mathrm{mg} / \mathrm{lit}$., $20 \mathrm{mg} / \mathrm{lit} ., 30 \mathrm{mg} / \mathrm{lit}$., $40 \mathrm{mg} / \mathrm{lit}, 50 \mathrm{mg} / \mathrm{lit}$ of nano adsorbent of $\mathrm{FeSO}_{4} \cdot 7 \mathrm{H}_{2} \mathrm{O}$ respectively Table. 7 .

Nitrate value of the raw effluent was 5.10 $\mathrm{mg} / \mathrm{lit}$ and decrease to $4.13 \mathrm{mg} / \mathrm{lit}, 3.87 \mathrm{mg} / \mathrm{lit}, 3.65$ $\mathrm{mg} / \mathrm{lit}, 3.41 \mathrm{mg} / \mathrm{lit}$, and $3.12 \mathrm{mg} / \mathrm{lit}$ with the addition of $10 \mathrm{mg} / \mathrm{lit}$., $20 \mathrm{mg} / \mathrm{lit}$., $30 \mathrm{mg} / \mathrm{lit}$., $40 \mathrm{mg} / \mathrm{lit}, 50 \mathrm{mg} /$ lit of nano adsorbent of $\mathrm{FeSO}_{4} \cdot 7 \mathrm{H}_{2} \mathrm{O}$ respectively Table. 7 .

\section{CONCLUSION}

From this study, we concluded that the retardation of chemicals from coloured effluents of dye industry and tanneries adsorption on metal nano particles useful for controlling water pollution. It was confirmed that higher removal of physico chemical pollutants from dye effluents adsorbent dose of more than $50 \mathrm{mg} / \mathrm{L}$ was favorable. Even though the removal efficiency of these three metal nano particles $\left(\mathrm{MgSO}_{4}, \mathrm{CuSO}_{4} \cdot 5 \mathrm{H}_{2} \mathrm{O}\right.$ and $\mathrm{FeSO}_{4} \cdot 7 \mathrm{H}_{2} \mathrm{O}$ ) are not much higher than other adsorbents, but in this method easy synthesis process of nano particles as well as chemicals used for this method easily available and very cheap. An attempt made to surroundings pleasant adsorbent big chemical pollutants elimination may be executed. So it may be substituting different pricey adsorbents. With the experimental data acquired in this study, it's far viable to design and optimize an economical treatment manner for the undesirable chemical compounds elimination from commercial effluents.

\section{REFERENCES}

1. Neamtu. M., Siminiceanu I., Yediler A. and Kettrup A., Dyes Pigments, 2002., 53, 93.

2. Jumaasiam. A., Chuab T.G., Gimbon J., Choong T.S. and Azmi I., Desalination, 2005., 186, 57.

3. Setamanit S., Fongasatitul P. and Sivadechathep J., ASEAN Acheivement and Future Directions in Pollution Control, Ministry of Science Tech. and Environ., Thailand, 2002, 27, 33.

4. Janas P., Buchtora H. and Ruzmarava M., Water Res., 2003, 37, 4938.

5. Mall I.D. and Upadhyay S.N., Indian J. Environ. Hlth., 1998, 40, 177.
6. Chen C.C., LiaU H. J., Cheng C.Y., Yen C.Y. and Chung Y.C., Biotechnol. Lett., 2007, 29, 391

7. Saha P., Chowdhury S., Gupta S., Kumar I. and Kumar R., Clean : Soil Air, Water., 2010, 38(56) 437 .

8. Rochat J., Demenge P. and Rerat J.C., Toxicol. Eur. Res., 1978 ., 1 .,23.

9. Adamson A.W.,"Physical chemistry of surfaces,"Inter Science publ.Inc., New york, 1960

10. Mckay G. , Oterburn M.S. and Sweeney A.G., Water Res., 1980, 14, 15.

11. Ho, Y.S., Porter, J.F., McKay, G.,. Water Air Soil Pollution, 2002, 141, 1-33. 